\title{
Seismic behavior of chilean bridges with seismic protection devices
}

\section{comportamiento sísmico de puentes nacionales con dispositivos de aislación}

María O. Moroni (Main Autor)

Universidad de Chile.

Facultad de Ciencias Fisicas y Matematicas, Depto. Ing. Civil

Blanco Encalada 2002, Santiago, Chile.

$+56229784376$

mmoroni@ing.uchile.cl

Mauricio Sarrazin (Contact Autor)

Universidad de Chile

sarrazin@ing.uchile.cl

\section{Abstract}

Several bridges with seismic protection systems have been built in the last decade in Chile. Accelerometer networks have been installed in some of them. Seismic records have been obtained by these instruments for moderate and severe earthquakes. In this paper, records registered at Marga Marga Bridge, Amolanas Bridge and Metro Viaduct are analyzed, and analytical models of the structures are developed. The parameters used in the models are adjusted using actual records in order to obtain the best fit between models and measured structural responses, in particular, frequencies and maximum displacement. The validated models are then used to estimate maximum stresses in principal elements and to compare them with nominal values given by design codes.

Keywords: Bridge, accelerometer network, seismic protection, analysis models, design code

\section{Introduction}

Marga Marga Bridge, built in 1996 , was the first bridge to have a seismic isolation system in Chile (Moroni, Sarrazin \& Herrera, 2011; Taylor, 2007). When fully completed, a network of 24 accelerometers for detecting the structure and free field response due to moderate and severe earthquakes was installed. The bridge is located in Viña del Mar on Marga Marga creek.

The earthquake (27F) of February 27, 2010, magnitude MW 8.8 (USGS Earthquake Hazard Program, Magnitude 8.8 - OFFSHORE MAULE, CHILE, 2010), was recorded on the bridge by 21 of 24 existing accelerometers, three of which are located at free field in the valley of the Marga Marga creek. Being the first severe earthquake recorded in an isolated bridge in Chile, the study of these records allows us to obtain valuable information about the performance of isolation systems and how they should be modeled to design structures in the future. The bridge records show high acceleration peak in the abutments, reaching values near $1 \mathrm{~g}$, while the maximum acceleration in the structure, away from the abutments, is $0.64 \mathrm{~g}$ in transverse direction and $0.57 \mathrm{~g}$ in longitudinal direction.

The Amolanas Bridge, which includes frictional isolators and Taylor type shock absorbers at the abutments, is located about $700 \mathrm{~km}$ from the epicenter of 27F. To date only moderate earthquakes records have been obtained in this bridge. In addition to the seismic records, it has also been measured through time the wind and temperature conditions, which represents a unique monitoring instrumentation for a bridge in Chile.

In viaduct of Line 5 Metro Santiago, there is a network of 12 accelerometers, which provided important information during the earthquake $27 \mathrm{~F}$ about levels of strains and stresses to

\author{
Braian Venegas \\ Universidad de Chile \\ braianvb@hotmail.com
}

Jorge Villarroel

Universidad de Chile

jovillarroelb@gmail.com

\author{
Manuscript Code: 549 \\ Date of Reception/Acceptance: 01/10/2014-01/03/2015
}

\begin{abstract}
Resumen
En los últimos años se han construido en el país varios puentes y viaductos que incluyen sistemas de aislación sísmica y disipación de energía. Algunos de ellos cuentan con redes de registro de aceleraciones que han operado durante los últimos sismos que han afectado al territorio nacional, obteniéndose valiosos registros. En este trabajo se presenta un análisis de los registros y del comportamiento de los puentes Marga Marga, Amolanas y del viaducto de la Línea 5 del Metro de Santiago ante estos sismos. El objetivo principal es validar modelos de análisis que den resultados realistas ante este tipo de solicitación con el fin de mejorar los métodos de diseño. Con dicho fin, se comparan frecuencias y desplazamientos máximos obtenidos de los registros con resultados de análisis dinámico no lineal, considerando como input los registros de aceleración de campo libre. Con los modelos validados se obtienen esfuerzos máximos alcanzados en elementos principales durante dichos eventos y se comparan con valores nominales de diseño.
\end{abstract}

Palabras Claves: Puente, red de acelerómetros, protección sísmica, modelos de análisis, código de diseño

which there piers were exposed

In what follows, a detailed analysis of the behavior of Marga Marga Bridge is presented and the characteristics of the other two structures are summarized.

\section{Marga Marga Bridge Description}

The Marga Marga Bridge is located in Viña del Mar, $\mathrm{V}$ region. It has a length of $383 \mathrm{~m}$, and is located in the northeast-southwest direction. It consists of eight segments that are supported by reinforced concrete $\mathrm{H} 30$ piers, whose height varies between 23.8 and $32.1 \mathrm{~m}$. The bridge has expansion joints at both abutments to allow longitudinal displacement.

The piers have a hollow rectangular section of $2 \times 10 \mathrm{~m}, 0.25$ $\mathrm{m}$ thick. At their ends, the dimensions of piers are $15.8 \mathrm{~m}$ wide and $2 \mathrm{~m}$ high, on the top side, and 10.5 to $13 \mathrm{~m}$ wide and 1.5 to $2 \mathrm{~m}$ high on the bottom side. The five interior piers ( 2 to 6 ) are supported by 10 circular section piles of $1 \mathrm{~m}$ diameter whose length varies between 14 and $32 \mathrm{~m}$.

The deck consists of a reinforced concrete H3O slab, whose section is $27 \mathrm{~cm}$ thick and $18 \mathrm{~m}$ wide. It is supported by four continuous steel I-beams, spaced $4.4 \mathrm{~m}$ apart, made of structural steel, whose minimum yield stress is $380 \mathrm{MPa}$, and with high resistance to atmospheric corrosion. The beams webs are $2.8 \mathrm{~m}$ high and their flanges width vary between 30 and 80 $\mathrm{cm}$. These beams are supported on high damping elastomeric isolators whose sections are $50 \times 50 \mathrm{~cm}$ (south abutment), $50 \times 70 \mathrm{~cm}$ (north abutment) and 55×85 cm (piers) and $30 \mathrm{~cm}$ high. They were manufactured by the national company Vulco SA. Each isolator consists of 17 layers of rubber $12 \mathrm{~mm}$ thick and 16 steel plates $3 \mathrm{~mm}$ thick.

Marga Marga Bridge is been monitored by an accelerome- 
ters network of 24 channels including devices Kinemetrics FBA-11 unidirectional and triaxial Kinemetrics FBA-23. A total of five triaxial accelerometers are installed, three of which are located at the top of pier 4 (central pier), a fourth is in close proximity to the central pier in soil and a fifth is near the south abutment founded on rock; the other 9 unidirectional sensors are arranged on the deck, as it is shown in Figure 1.

\section{Maule Earthquake Records}

Table 1 shows the absolute maximum accelerations of all channels for unfiltered and filtered records (between 0.2 and $20 \mathrm{~Hz}$ ) obtained during the $27 \mathrm{~F}$ earthquake. By filtering the records, a significant reduction in the maximum accelerations can be seen in the devices located at the abutments. This is due to the high frequency content of these records, probably as result of impacts between the bridge and the side guides. Despite of high peak accelerations recorded on the bridge, no damage was reported in the structure. Records at the bottom of pier 4 are similar to those obtained at free field.

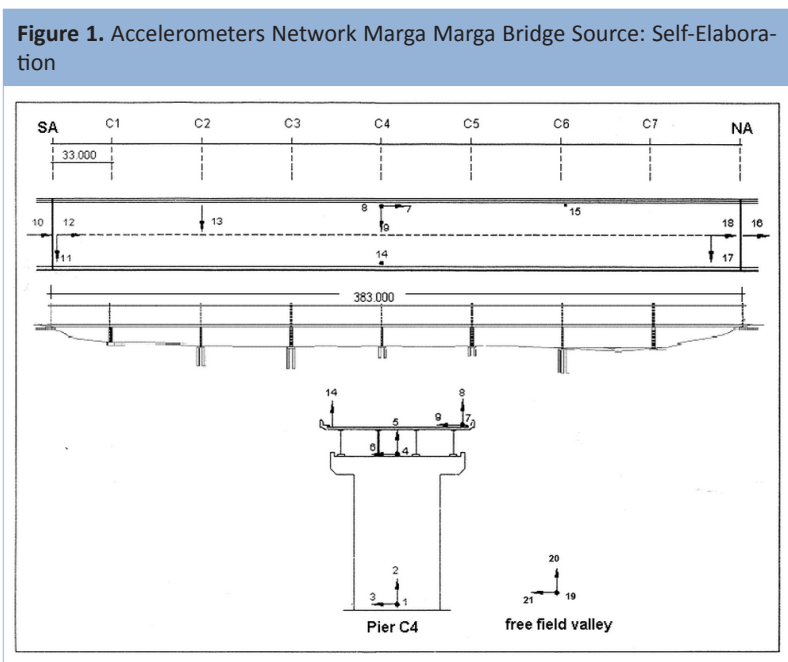

Table 2 presents the main bridge modal frequencies obtained from the power spectra of the acceleration records. Also, damping of the first modes (obtained by bandwidth method) are presented. Modal damping with an asterisk corresponds to those obtained from the end of the record. Note that the first modes of the structure in longitudinal and transverse directions are controlled by the isolation system, having a period of $2.5 \mathrm{~s}$ on the deck over the central pier. This value is higher than the period considered during the design stage. Acceleration records were integrated to obtain the maximum displacements in the structure. Table 3 contains the maximum relative displacements of the isolation system during the earthquake. As can be seen, the maximum shear strain of the isolators is between $27 \%$ and $77 \%$.

Figure 2 shows the peak accelerations ratio between pairs of channels vs peak acceleration at the valley, for earthquakes and aftershocks whose maximum acceleration in the structure is equal to or greater than $0.09 \mathrm{~g}$. Decrease of the maximum acceleration ratio between free field (soil) and the deck in longitudinal and transverse directions due to the action of the isolation system is apparent, while the contrary occurs in the vertical direction.

\begin{tabular}{|c|c|c|}
\hline Channel & $a_{\max }$ not filtered [g] & $a_{\max }$ filtered $[\mathrm{g}]$ \\
\hline 1 & 0.35 & 0.34 \\
\hline 2 & 0.16 & 0.15 \\
\hline 3 & 0.37 & 0.38 \\
\hline 4 & 0.57 & 0.57 \\
\hline 5 & 0.18 & 0.17 \\
\hline 6 & 0.53 & 0.52 \\
\hline 7 & 0.28 & 0.16 \\
\hline 8 & 0.34 & 0.21 \\
\hline 9 & 0.64 & 0.56 \\
\hline 10 & 1.05 & 1.00 \\
\hline 11 & 1.98 & 1.37 \\
\hline 12 & 0.32 & 0.23 \\
\hline 13 & 0.64 & 0.46 \\
\hline 14 & 0.27 & 0.24 \\
\hline 15 & 0.58 & 0.53 \\
\hline 16 & 0.41 & 0.38 \\
\hline 17 & 1.39 & 0.93 \\
\hline 18 & 0.27 & 0.17 \\
\hline 19 & 0.35 & 0.35 \\
\hline 20 & 0.26 & 0.25 \\
\hline 21 & 0.34 & 0.34 \\
\hline
\end{tabular}

\begin{tabular}{c|c|c|c}
\multicolumn{4}{c}{ Table 2. Frequency analysis, 27F earthquake. Source: Self-Elaboration } \\
\hline Direction & Frequency [Hz] & $\begin{array}{c}\text { Damping } \beta \\
{[\%]}\end{array}$ & Location \\
\hline Longitudinal & $0.40-0.42$ & $19.5^{*}$ & Deck \\
\hline Longitudinal & $1.01,1.21$ & 5.0 & Valley \\
\hline Longitudinal & $1.48-1.61$ & 1.6 & Pier \\
\hline Transverse & $0.42-0.46$ & $18.4^{*}$ & Deck \\
\hline Transverse & $0.92,1.05$ & $5.3,3.1$ & Valley \\
\hline Transverse & 2.71 & - & Pier - Deck \\
\hline Vertical & $2.35-2.37$ & - & Deck \\
\hline Vertical & 4.26 & - & Valley \\
\hline
\end{tabular}

\begin{tabular}{c|c|c|c|c}
\multicolumn{4}{c}{ Table 3. Maximum relative displacements in isolation system, 27F earthquake } \\
\hline Direction & Channels & Location & $d_{\max }[\mathrm{cm}]$ & $\gamma[\%]$ \\
\hline Longitudinal & $7-4$ & Pier & 10.94 & 53.6 \\
\hline Longitudinal & $18-16$ & $\begin{array}{c}\text { North } \\
\text { Abutment }\end{array}$ & 6.08 & 29.8 \\
\hline Longitudinal & $12-10$ & $\begin{array}{c}\text { South } \\
\text { Abutment }\end{array}$ & 5.59 & 27.4 \\
\hline Transverse & $9-6$ & Pier & 15.60 & 76.5 \\
\hline
\end{tabular}

Figure 3 shows the variation of the fundamental frequency during the Maule earthquake and aftershocks, while Figure 4 shows the damping variation of the first mode for the same earthquakes, in longitudinal and transverse directions. In the case of frequency as function of the acceleration of the valley, it is clear that the seismic isolators make the structure more flexible, being the effect greater as larger is the basal acceleration. The fundamental frequency is close to 0.85 $\mathrm{Hz}$, for smaller aftershocks, reaching $0.42 \mathrm{~Hz}$ during Maule earthquake. 
Moreover, the damping increases with the level of seismic demand, starting at around $4 \%$ for small earthquakes up to about $19 \%$ for Maule earthquake, although in this case the trend is not so clear. Frequencies of the order of $1.2 \mathrm{~Hz}$ are obtained from the records of the valley, similar to the frequency determined previously for moderate earthquakes and micro vibrations .

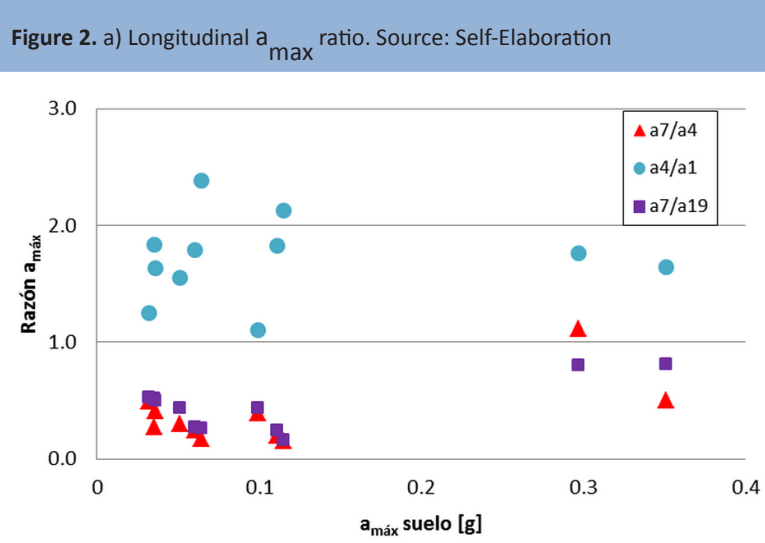

b) Transverse $a_{\text {max }}$ ratio

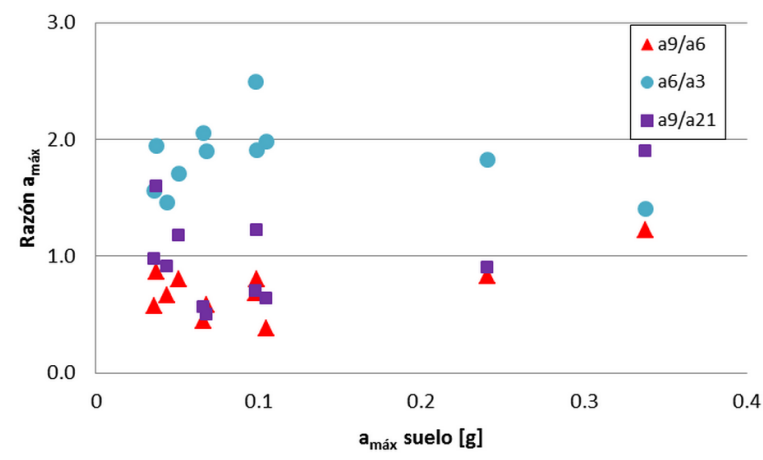

c) Vertical $a_{\text {max }}$ ratio

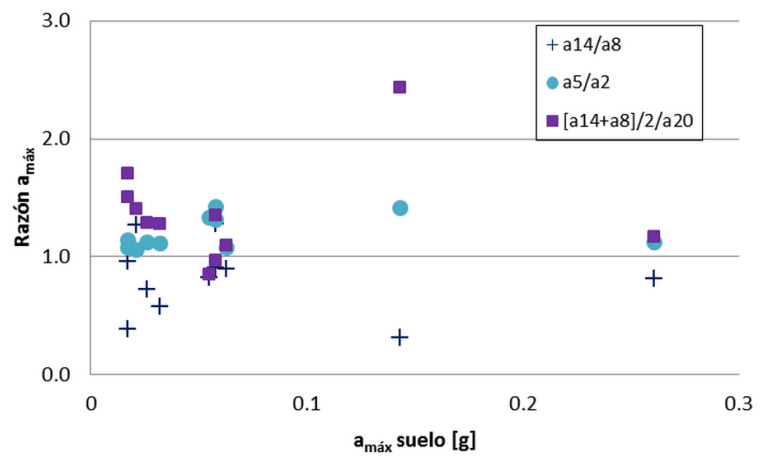

Figure 3. a) Fundamental mode frequency in longitudinal direction Source: Self-Elaboration

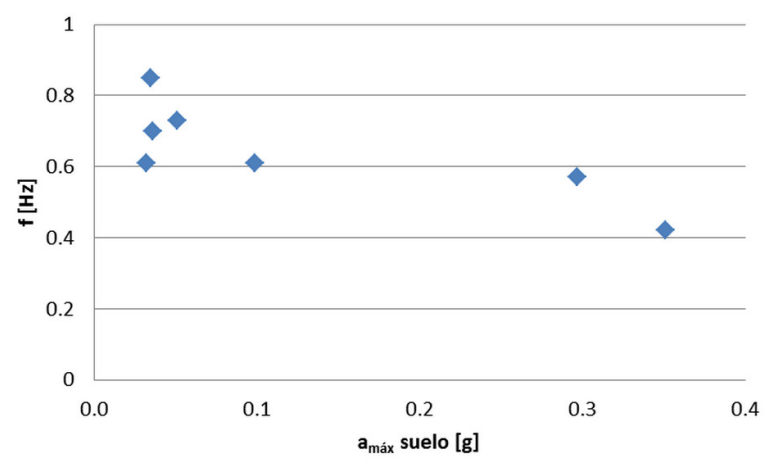

b) Fundamental mode frequency in transverse direction

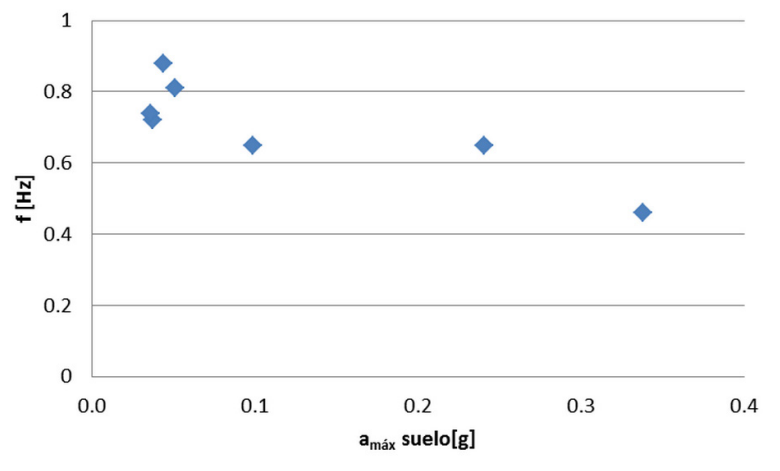
Figure 4. a)Fundamental modal damping in longitudinal direction. Source: Self-Elaboration

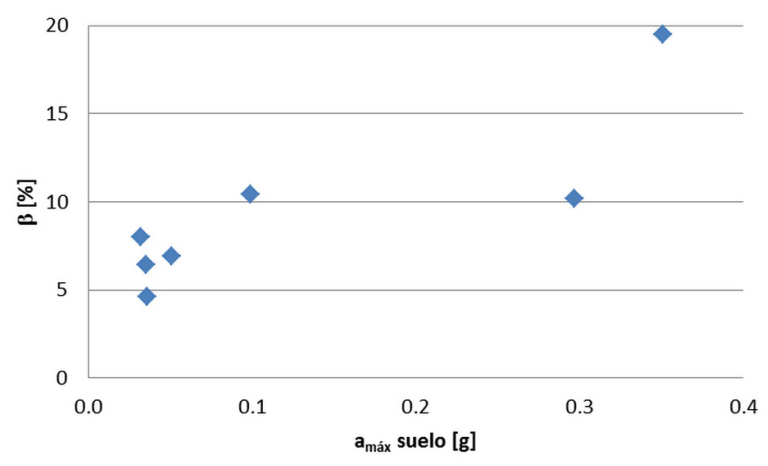

b) Fundamental modal damping in transverse direction

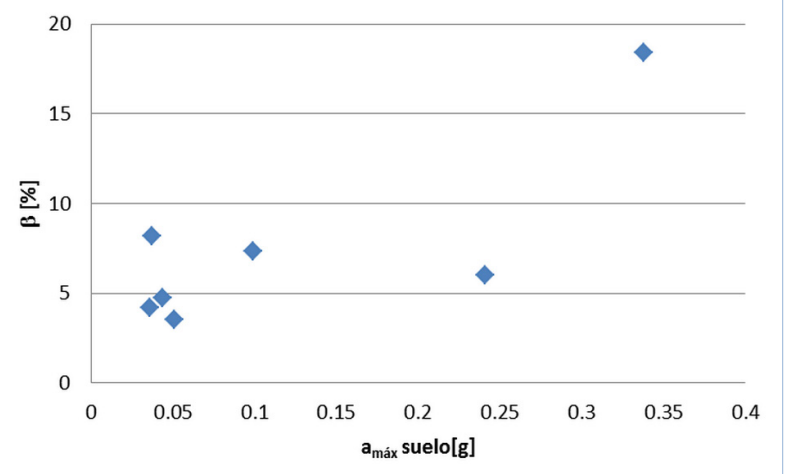


Finite Elements Model

A finite element model of Marga Marga Bridge was developed in OpenSees software and it was analyzed considering asynchronous input. Thus, piers 2 to 5 were subjected to the valley acceleration records, pier 1 was subjected to the South abutment records and piers 6 and 7 were subjected to the North abutment records. The model includes 682 nodes and 1102 elements (Venegas, 2013). The masses of the whole structure are automatically assigned to the nodes. The total weight of the structure is 11,500 tons. Piers were considered fixed at the base. Additional restrictions were added at the junction between the deck and the abutments in the longitudinal direction in order to represent the tooth expansion joints and the side guides present at that location.

Figure 5 shows a diagram of the elements used to model the bridge. The isolators are represented by nonlinear elements, while linear elements are used for piers, steel beams and deck; all items are Frame type elements. Rigid elements were used to join the elements. $2 \%$ damping for modes 1 and 3 was considered.

Figures 6 and 7 show the displacements and spectral densities (theoretical and experimental) obtained on the deck in the longitudinal (sensor 7) and transverse directions (sensor 9). Very good correlation is observed in the longitudinal direction, both in displacements and predominant frequencies. However, in the transverse direction the model is not able to reproduce the predominant frequencies.

Figure 8 shows hysteresis loops obtained experimentally for one of the isolators for different relative displacements (Teneo, 2000) and those obtained by time-history analysis over pier 4 . The equivalent stiffness calculated as the ratio of the difference between maximum and minimum values of forces and displacement is $1737 \mathrm{kgf} / \mathrm{cm}$, similar to the value considered during the phase design: a stiffness of $1700 \mathrm{kgf} / \mathrm{cm}$ for a deformation of $16 \mathrm{~cm}$.

The bending and shear forces obtained at the bottom of the piers were compared with the nominal capacities of these elements, according to AASHTO 2002. Figure 9 shows the interaction diagrams for pier 4 on both weak and strong axis, and the internal forces obtained from time-history analysis (Villarroel, 2013). In general, the internal forces were contained within the boundaries of interaction diagrams, surpassing them only at brief moments.

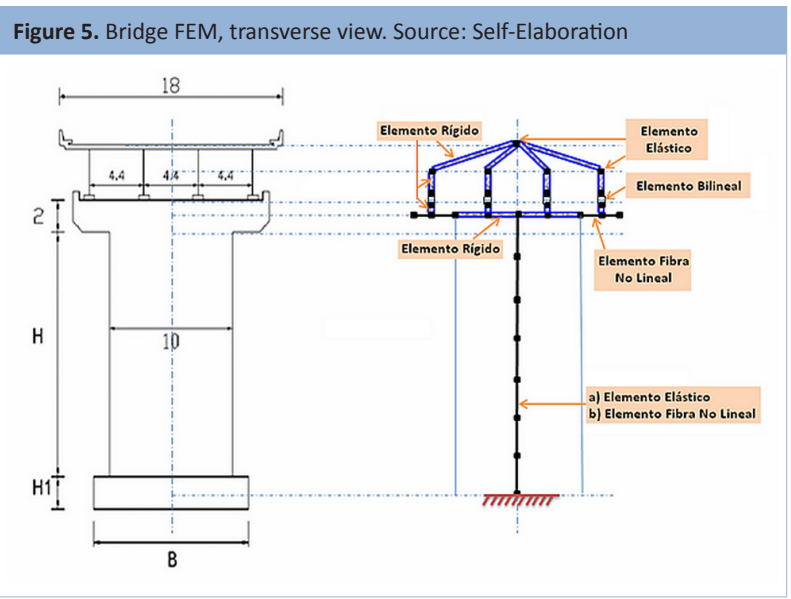

Figure 6. Displacement on the deck over pier 4, longitudinal direction. Source: Self-Elaboration
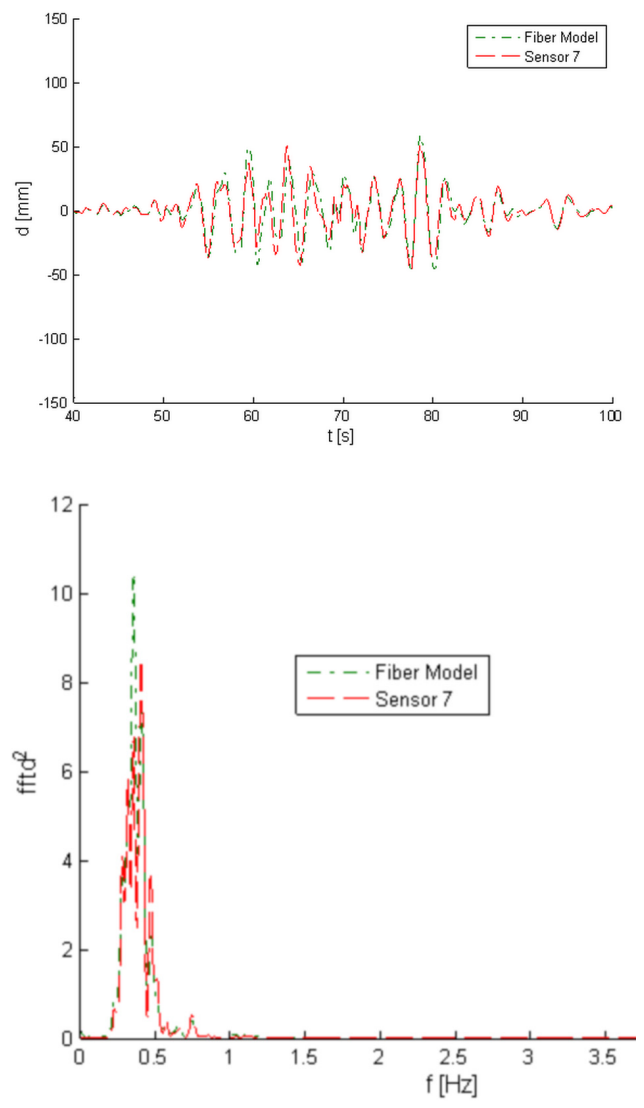

Figure 7. Displacement on the deck over pier 4, transverse direction. Source: Self-Elaboration
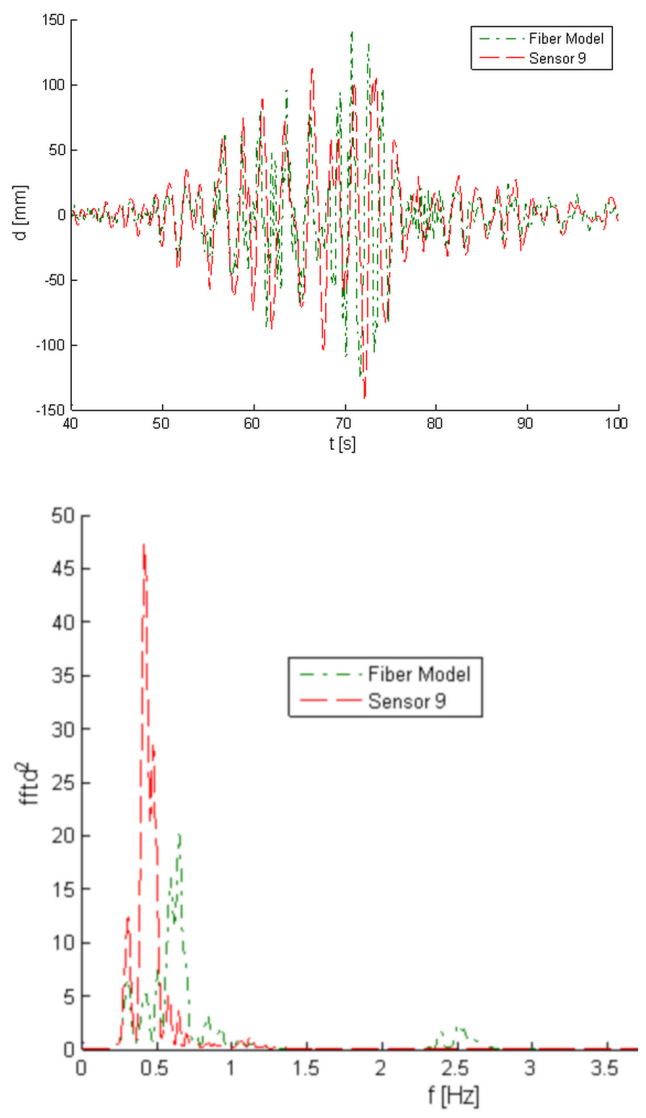

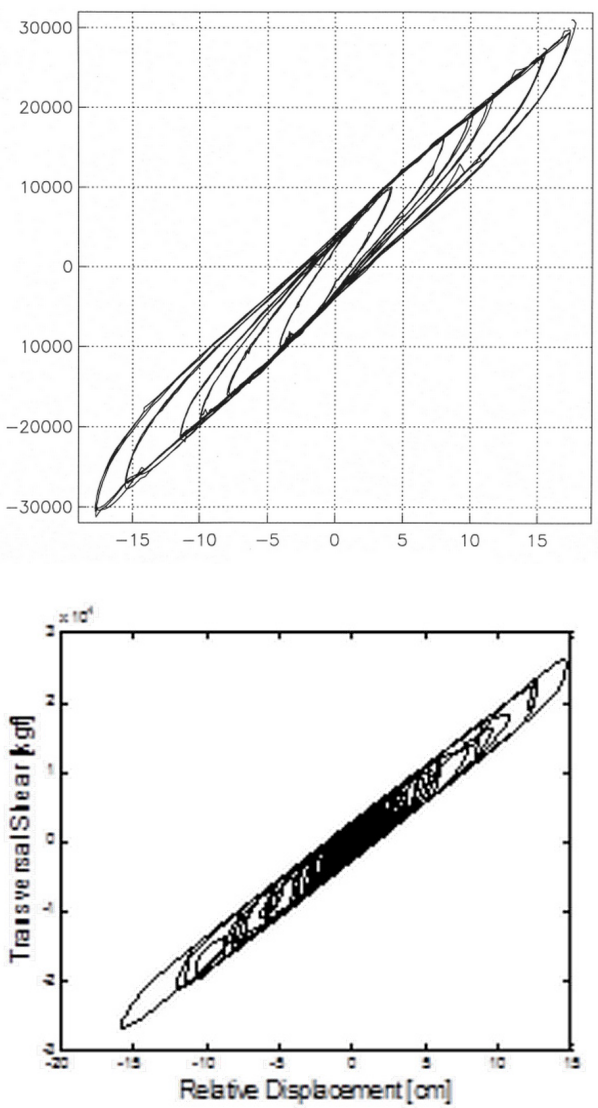

Figure 9 a) Pier 4 - Interaction diagrams weak axis. Source: Self-Elaboration

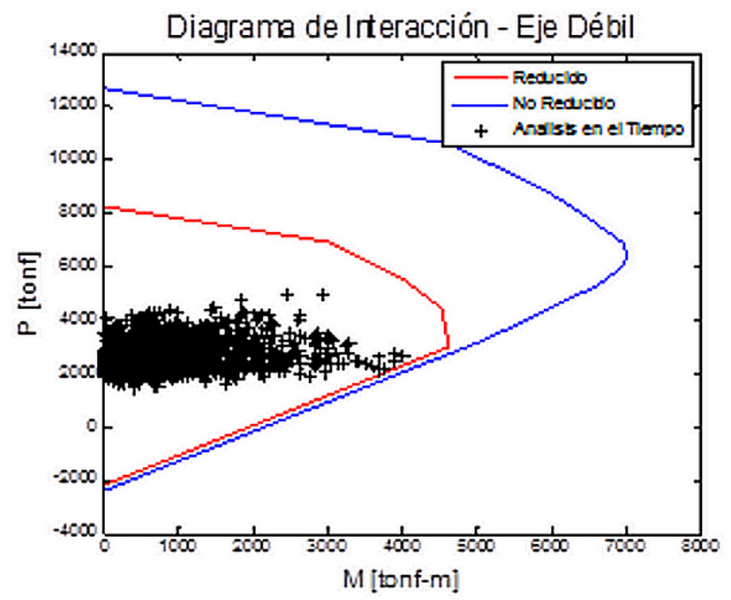

b) Pier 4 - Interaction diagrams strong axis

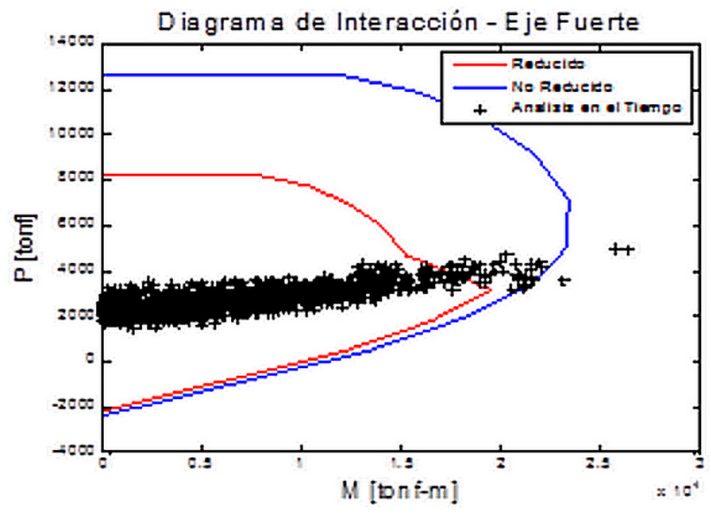

The situation is quite different for shear forces; there are significant differences between the values of nominal capacity and maximum values reached during time history analysis. However, piers showed no damage, which suggests that nominal capacities are greater than values prescribed by the design regulations.

\section{Amolanas Bridge}

The Amolanas Bridge, located $309 \mathrm{~km}$ North of Santiago, is the first bridge in Chile equipped with sliding bearings and viscous dampers to absorb seismic movements. These devices can substantially reduce the forces induced by earthquakes on deck, piers and abutments. This bridge also has other important features such as a pier of $100 \mathrm{~m}$ high, continuous steel beam box-shaped section $268 \mathrm{~m}$ long, and a deck made of post-tensioned concrete that overhangs at their sides shored up with inclined steel elements.

The year 2000, a network of accelerometers was installed on the bridge and it has been recording at the site continuously since then. In addition, an anemometer to register speed and wind direction, parameters needed to determine the wind forces on the structure, and a network of temperature sensors located in different parts of the steel beam and deck have been also installed. Finally, sensors that measure relative displacements were installed at the sliding bearings over piers and abutments. This network aims to measure the magnitude of permanent displacements and to check that there are no interferences with the tolerances required due to earthquakes. To date, only moderate earthquakes records has been obtained. Maximum wind speed has reached up to $56 \mathrm{~km} / \mathrm{h}$, much lower value than the $95 \mathrm{~km} / \mathrm{h}$ considered in the design. Mean temperatures have varied between 12 and $22{ }^{\circ} \mathrm{C}$. Detailed information about these measurements is in Sarrazin et al (2005).

\section{Line 5, Santiago Metro}

Santiago Metro Line 5 has an elevated part $5810 \mathrm{~m}$ long, that includes stations: Rodrigo Araya, Carlos Valdovinos, Camino Agrícola, San Joaquin, Pedrero and Mirador. Structurally, the viaduct consists of post-tensioned concrete slabs of $30 \mathrm{~cm}$ thick, 27 to $36 \mathrm{~m}$ long and 6.3 to $7.5 \mathrm{~m}$ width. The slabs are supported by two outer prestressed concrete beams, $1.80 \mathrm{~m}$ high, connected to the slab at its lower flange by transverse post-tensioning.

The beams are simply supported and connected to the ends of reinforced concrete capitols through neoprene bearings whose section is $30 \times 60 \times 5.2 \mathrm{~cm}$. The capitols are monolithically connected to hollow central columns whose section is $2.4 \times 1.4 \mathrm{~m}$ and $30 \mathrm{~cm}$ the wall thickness. Columns located at the stations are $2.4 \times 2.2 \mathrm{~m}$. The columns are monolithically connected to their foundations, which consist of a hollow reinforced concrete parallelepiped, whose depth varies between 7 and 12 meters. The foundations are filled with properly compacted soil. Detailed information is in Sarrazin et al. (2002).

The instrumentation installed at Metro Line 5 is a local network that consists of three uniaxial accelerometers FBA-11 located at both extreme of the deck and three triaxial accelerometers FBA-23 of Kinemetrics, located at the free field and at the top and bottom of one column. Frequencies shown in Table 4 were obtained from records of moderate earthquakes in the longitudinal, transverse and vertical directions. 
Table 4. Variation range of frequencies, moderate earthquakes. Source: Self-Elaboration.

\begin{tabular}{l|l|l|l}
\hline \multirow{2}{*}{ Mode } & \multirow{2}{*}{ Direction } & Frequency $(\mathrm{Hz})$ \\
\cline { 3 - 4 } & & Mínimum & Máximum \\
\hline 1 & Longitudinal & 1.5 & 2.6 \\
\hline 2 & Transverse & 1.4 & 2.4 \\
\hline 3 & Vertical & 2.6 & 3.1 \\
\hline
\end{tabular}

Figure 10. Records obtained during 27F earthquake Line 5 Santiago Metro. Source: Self-Elaboration.

a) Longitudinal direction
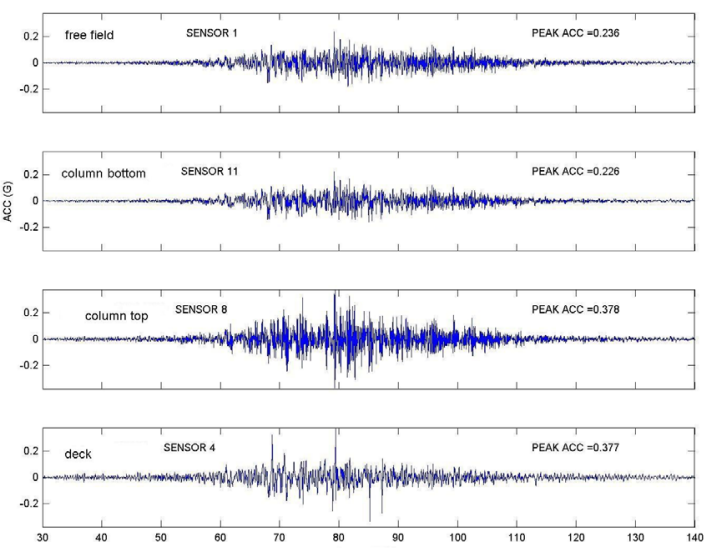

b) Vertical direction

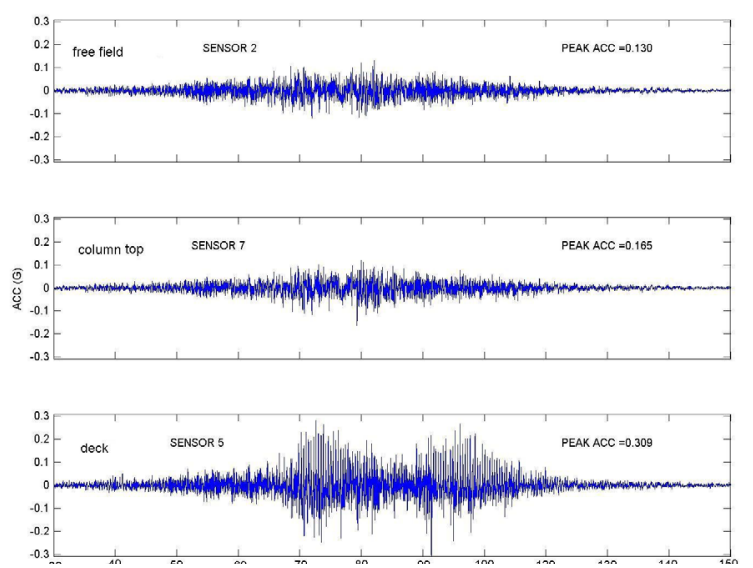

c) Transverse direction

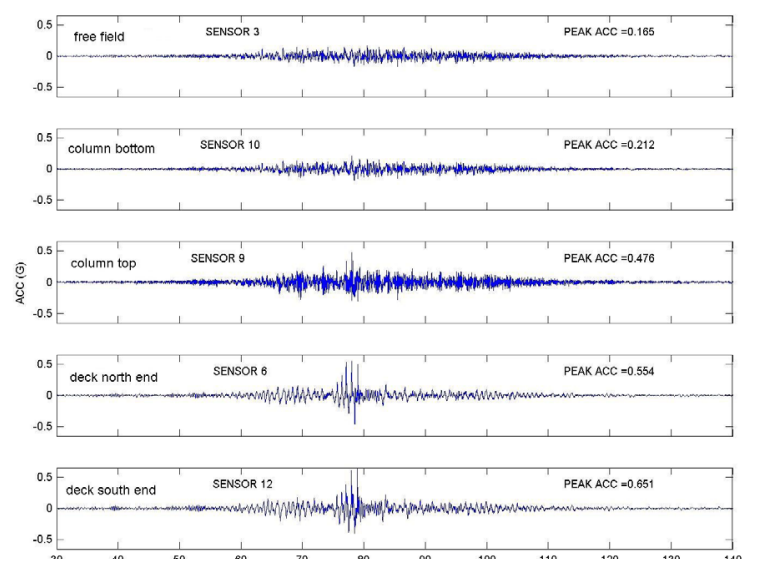

Metro continued operating normally after 27/02/2010 earthquake, except for some minor damage on non-structural elements at some stations. Records obtained on 27/02/2010 are presented in Figure 10. The records at the free field and at the bottom of the pier are similar, which means that there is not soil structure interaction. On the other hand, there is an amplification of around 2 between the bottom and top of the pier in both horizontal directions. Then, there is a reduction between the top of the pier and the deck in both horizontal directions and substantial changes in the frequency content. Horizontal records of channels 6 and 9 are quite similar. In the vertical direction there are amplifications between sensors 2-5 and 7-5.

From signal analysis, the following frequencies were identified: $1.25 \mathrm{~Hz}$ in transverse direction, $1.43 \mathrm{~Hz}$ and 2.5 $\mathrm{Hz}$ in longitudinal direction and $2.5 \mathrm{~Hz}$ in vertical direction. Relative displacements at isolation system level are about 2 $\mathrm{cm}$, equivalent to $55 \%$ of shear strain. The equivalent damping is less than $2 \%$.

\section{Conclusions}

During 27F, in Marga Marga Bridge, the seismic isolation system was effective in reducing the accelerations on the deck in longitudinal and transverse directions. Only at abutments peak accelerations of $1 \mathrm{~g}$ were recorded, probably as result of impacts between deck and abutments.

It has to be emphasized that the dynamic response of the structure is non-linear, and that it depends on the magnitude of the ground motion. The main frequencies vary between 0.85 and $0.4 \mathrm{~Hz}$ in the longitudinal direction and between 0.8 and $0.42 \mathrm{~Hz}$ in transverse direction.

The model developed in OpenSees, including gap type elements between the deck and the abutments in the longitudinal direction, and asynchronous input, produced a marked response improvement over previous models in both, maximum displacements and frequency. Similar acceleration reductions were observed in horizontal direction at the Line 5 Metro Viaduct in Santiago.

Finally, it is essential to install more accelerometer networks in bridges in Chile, especially in those located in areas where major structural damage occurred during the $27 \mathrm{~F}$ earthquake, specially on skewed bridges (Sarrazin, Santa María \& Moroni, 2012) and/or due to local soil amplification effects (Verdugo et al., 2012). In long bridges with connectivity importance as Chacao Channel Bridge, the investment in instrumentation represents a small amount of the total project cost. Moreover, it is important to have continuous monitoring in order to update the properties of the bridges over time, as proposed by Sanayei (Sanayei et al., 2012). In this way it is possible to detect changes in the structures that may indicate weakening due to earthquakes, accidents, damage caused by the action of environment or other, and take actions to repair or reinforce them.

\section{Acknowledgements}

This work is been possible thanks to financial support from the following institutions: University of Chile, MOP, METRO de Santiago and Fondecyt. 
Moroni, M.O., Sarrazin, M. \& Herrera, R. (2011) Research Activities in Chile on Base Isolation and Passive Energy Dissipation. 12th World Seminar on Seismic Isolation, Energy Dissipation and Active Vibration Control of Structures, Sochi.

Sanayei, M., Phelps, J., Sipple, J., Bell, E. \& Brenner, B. (2012) Instrumentation, Nondestructive Testing, and Finite-Element Model Updating for Bridge Evaluation Using Strain Measurements. Journal of Bridge Engineering, 17 (1), 130-138.

Sarrazin, M., Moroni M.O., Romo D., Quintana J., \& Soto P. (2002) Respuesta sísmica de puentes chilenos con apoyos aislantes, Rev. Int. De Desastres Naturales, Accidentes e Infraestructura Civil, 2(2),31-48 (Spanish).

Sarrazin, M., Moroni M O., Beltrán C., Farías E., Riquelme D. (2005) Puente Amolanas: Alto nivel en protección sísmica, Revista BIT, 12(42), 42-46.

Sarrazin, M., Santa María, H. \& Moroni, M.O. (2012) Efectos en caminos y puentes. In Mw=8.8 Terremoto en Chile 27 de febrero 2010, (pp 271-286), Civil Enginnering Department, Faculty of Physical and Mathematical Sciences, University of Chile (Spanish).

Taylor, D. (2007) Calibración del Modelo del Puente Marga Marga Considerando Variación Espacial del Movimiento Sísmico a Nivel de Cepa y Estribo, Civil Engineering Thesis, University of Chile (Spanish).

Teneo, M. (2000) Ensayos de prototipos de aisladores sísmicos del Puente Marga Marga, Civil Engineering Thesis, University of Chile (Spanish).

USGS, Earthquake Hazard Program, Magnitude 8.8 - OFFSHORE MAULE, CHILE (2010), february 27. Retrieved from http:// earthquake.usgs.gov/earthquakes/eqinthenews/2010/us2010tfan/.

Venegas, B. (2013) Análisis del Comportamiento Dinámico del Puente Marga Marga Sometido al Terremoto del 27 de Febrero De 2010, Santiago: M Sc Seismic Engineering Thesis; Civil Engineering Thesis, University of Chile (Spanish).

Verdugo, R., González, J., González, V. \& Torres, A. (2012) Características y efectos del fenómeno de licuefacción. In $M w=8.8$ Terremoto en Chile 27 de febrero 2010, (pp. 63-106), Civil Enginnering Department, Faculty of Physical and Mathematical Sciences, University of Chile (Spanish).

Villarroel, J. (2013) Determinación de Esfuerzos en las Cepas del Puente Marga Marga a Partir de Registros Sísmicos del Terremoto del 27 de Febrero de 2010, Civil Engineering Thesis, University of Chile (Spanish). 